\title{
Collective Bargaining and Technological Investment: The Case of Nurses' Unions and the Transition from Paper-Based to Electronic Health Records ${ }^{\dagger}$
}

\author{
Adam Seth Litwin \\ Associate Professor of Industrial \& Labor Relations \\ ILR School \\ Cornell University \\ aslitwin@,cornell.edu / @,ProfASLitwin
}

(version: May 10 $\left.0^{\text {th }}, 2017\right)$

(forthcoming in the British Journal of Industrial Relations)

\begin{abstract}
Does the presence of a unionized nursing workforce retard U.S. hospitals' transition from paper-based to electronic health records (EHRs)? After tying archival data on hospitals' structural features and health information technology (IT) investment patterns to self-gathered data on unionism, I find that hospitals that bargain collectively with their registered nurses (RNs) appear to delay or forego the transition away from paper, consistent with existing theory and research in industrial relations and institutional economics. However, this relationship is fully mediated by a hospital's payer mix: those serving a larger share of less lucrative, elderly, disabled, and indigent patients are more likely to adopt EHRs if they are unionized than if they are not, a result that holds even at the median payer mix. Indeed, this accords with research on the interplay of labour and technology as the aforementioned dynamics are driven entirely by $\mathrm{RN}$-exclusive bargaining units for whom the new IT serves as a complement rather than as a substitute in production. Given the outsized role that unions play in the U.S. healthcare sector, the overall sluggish performance of the sector, and the expectations that policymakers have for EHRs, evidence that these unions are welfare-enhancing should be welcome news.
\end{abstract}

Key words: nurses' unions; health information technology (IT); healthcare workforce; electronic health records (EHRs); labour relations; collective bargaining; bargaining structures.

\footnotetext{
${ }^{\dagger}$ Ariel Avgar, John Budd, Paul Clark, Louisa Heywood, David Metcalf, and Ben Rissing provided helpful comments toward the development of this manuscript, and Nick Krachler helped to shed light on bargaining structures for registered nurses in the state of New York. Thanks to Suzanne Cohen and Aliqae Geraci of Cornell University's Catherwood Library for help in procuring and navigating data from the American Hospital Association and Bloomberg/BNA, respectively, as well as to Elizabeth A. Ashack and Audrey Watson of the U.S. Bureau of Labour Statistics for detailing the construction of national wage and employment data. Jinyoung Park and Thomas Slabowski provided reliable and timely research assistance.
} 


\section{Introduction}

The question of whether or not unions and collective bargaining inhibit business investment once captured the fascination of researchers and the concern of politicians and policymakers (Simons 1944; Slichter et al. 1960). After all, to the extent that unions could be credibly blamed for hindering capital accumulation, one could also reasonably accuse them of slowing economic growth and eroding competitiveness writ large (Metcalf 2003) — not to mention sowing the seeds of their own demise by curtailing the number of unionized employers (Menezes-Filho and Van Reenen 2003). Yet, with private sector union density in the U.S. below 7\%, one can imagine many other more viable culprits for most of the country's and the developed world's economic ills.

Despite the apparent evaporation of an urgent need for a 'grand theory' to explain the influence of collective bargaining on investment, those concerned with the performance of one sector, in particular-healthcare-would be remiss to discharge this issue as purely academic. Close observers of the U.S. healthcare sector have noted two parallel phenomena. First, despite the structural, economy-wide decline in collective bargaining, healthcare unionism has proven resilient and, in fact, a bright spot for union organizers (Avgar et al. 2016). While union membership declined by about 200,000 workers nationwide over the period 2012-2014, the healthcare sector added 47,000 new union members (Bloomberg/BNA 2015). Moreover, the insurance mandate embedded in the Obama-era Affordable Care Act (ACA) is expected to exacerbate existing unmet demand for skilled healthcare workers-registered nurses (RNs), in particular-extending the period of relative labour market power for the largest single group of employees in our nation's hospitals (Clark 2013; Juraschek et al. 2012).

Second, whereas nearly every sector in the U.S. embraced the digital revolution of the late $20^{\text {th }}$ century, healthcare long persisted as the singular holdout (Porter and Teisberg 2006). Recordkeeping in U.S. hospitals remained largely paper-based until the federal government as part of its 2009 economic stimulus package started favouring those hospitals adopting electronic health record (EHR) systems with more generous reimbursement rates for Medicare and Medicaid, the social welfare programs that fund care for the elderly, disabled, and indigent. Consequently, even as late as 2012, fewer than half of the nation's general acute care hospitals claimed to have installed what Adler-Milstein et al. (2015) and Jha et al. (2009), among others, define as a 'basic' EHR system. 
Taken together, these two stylized facts beg the question: has collective bargaining, particularly on the part of registered nurses, effectively retarded hospital investments in EHRs? Indeed, if this is the case, then one can still reasonably point to collective bargaining as the culprit for the sector's abysmal performance over time relative to other others domestically and to the healthcare systems of other nations. And, given the centrality of this sector to a high-functioning civil society and economy, this accusation could not be ignored.

I attempt to answer this question by drawing theory from seminal work in labour relations as well as from more recent, economics-oriented research to predict the mechanisms by which the union status of nurses in a given hospital should influence whether and when it adopts an EHR system, controlling for structural characteristics of the hospitals themselves. In the aggregate, these literatures meld to suggest that the association between collective bargaining and investment ${ }^{1}$ in this context should be a negative one, just as implied by those taking note of the ‘dual phenomena' of robust nurse unionism and glacial hospital EHR adoption.

This paper seeks to pin down this relationship using a panel dataset of New York State hospitals constructed from industry and government sources. In the net, the findings are at odds with the thrust of existing theory and the received body of empirical research examining the relationship between collective bargaining and investment. I find very limited evidence of a negative association between $\mathrm{RN}$ unionism and $\mathrm{EHR}$ adoption. In fact, once one accounts for the composition of patients or payers served by a hospital, the net effect of nurses' unions on health IT investment turns positive, a result that strengthens as the share of a hospital's patient days exhausted by elderly, disabled, and indigent patients increases. From this, one can infer that nurses' unions encourage hospital administrators to invest in health IT where a hospital's resources and payer stream would not otherwise beget investment, a heretofore unrealized mechanism by which unions enhance social welfare. I then turn back to the data and exploit variation in bargaining structures to show that the behaviour of nurses' unions, however beneficial to society, may well be predicated on economic self-interest arising from production complementarities.

The paper proceeds as follows. It first offers background on the sector including the role of nurse unionism within it as well as its recent transition from paper records to EHRs. Then, I review two strands of research, the intermingling of which provides a strong prior that $\mathrm{RN}$ unionism plays a role in U.S. hospitals' halting and delayed adoption of EHRs. I then detail the data and empirical methods in the subsequent section, after which I present estimation results. 
These results push me to explore potential explanations for the findings. The paper concludes by suggesting important next steps for those wanting to better understand the relationship between collective bargaining and technological investment.

\section{Background}

\section{The U.S. Healthcare Sector and Electronic Health Records (EHRs)}

Much of the attention garnered by the U.S. healthcare sector arises from the fact that government itself and thus, voting taxpayers, foot almost half of the nation's healthcare bill annually. The scrutiny also stems from the sector's anomalously poor economic performance. As reported in Avgar et al. (2016), in 2014, the U.S. spent 50\% more per capita on healthcare than the next closest country, and the sector exhausted $17.5 \%$ of total GDP. Furthermore, costs have long risen faster than those in the rest of the economy and are expected to continue outpacing those of other sectors over the next 20 years (CMS 2015). Even more alarmingly, these expenditures do not yield quality care as the U.S. healthcare sector suffers below-average life expectancies and above-average rates of medical errors and infant mortality relative to other advanced, industrialized nations. And, this all transpires despite a long-term shift towards increased competition, some of which has been engendered by payment reform and the transition from the fee-for-service to the managed care model.

Until recently, almost none of the escalating healthcare expenditures were going toward comprehensive electronic recordkeeping. Many Americans are still confronted with manila folders full of paper records when visiting a doctor's office. And, the same was long true at U.S. hospitals as well. Figure 1 shows what I alluded to above: even as late as 2012, fewer than half of the nation's general acute care hospitals claimed to have installed even a 'basic' EHR system. In 2008, the first year for which there exists comparable data, EHR uptake among the same group was below 10\% (Jha et al. 2009).

\section{[-------- Insert Figure 1 about here. ---------]}

Despite genuine attention from the George W. Bush administration, the real impetus for adoption did not come about until the passage of the Health Information Technology for Economic and Clinical Health Act (HITECH), the name for Title XIII of the American Recovery and Reinvestment Act of 2009. The act earmarked $\$ 18$ billion as incentives for hospitals and physicians who demonstrate meaningful use of certified EHR systems. 


\section{Nurse Unionism in the U.S.}

Personnel costs are the largest line item in most hospital budgets, and RNs compose the largest occupational group within these budgets (Kangas et al. 1999). Consequently, increases in competitive and budget pressures such as those arising from payment reforms and managed care impact the daily work lives of nurses perhaps most directly and most negatively of all those employed in the acute-care hospital sector. Indeed, Clark (2013) outlines the different ways that healthcare reform, sectoral restructuring, and resulting increases in market competition in the U.S. have led to increased workloads, increased stress, and lower job satisfaction for hospitalbased RNs. Aside from the psychological costs imposed on RNs, the result has been a national, structural 'shortage’ of nurses (Littlejohn et al. 2012; Snavely 2016).

Evidence of this supposed shortage comes from Figure 2. Panel (a.) shows that employment has grown more quickly for RNs than it has across the U.S. economy overall, and panel $(b$.) demonstrates that the growth in employment was paralleled by a growth in wages slightly larger than across-the-board wage growth. Panels $(c$. $)$ and $(d$.$) together further suggest that registered$ nurses have power in the labour market and in their workplaces. Panel (c.) displays absolute levels of union density for RNs. As of $2015,17.8 \%$ of RNs in the U.S. were unionized, down from a pre-recession peak of $19.8 \%$ but slightly ahead of 1991 levels. Furthermore, the structural decline in absolute private sector union density shown in the same panel suggests that nurses have done quite well for themselves on this measure relative to others in the labour market. Panel $(d$.) punctuates this point by showing relative changes in these two series.

[-------- Insert Figure 2 about here. -------- ]

What are the implications of the presence and power of nurses' unions on a hospital's orientation toward investments in EHR systems and health IT more broadly? In the U.S., hospital management does not have to bargain 'in good faith' over technological changes in production as it is obligated to do over wages and conditions of employment. Nonetheless, where a union has been recognized for the purposes of collective bargaining, management does have to bargain over the workplace and workforce effects of these investments in technological capital. This suggests that hospitals with a unionized RN workforce face greater hurdles to monetizing capital investments in EHR systems than would otherwise similar nonunion hospitals. 


\section{Theory and Research}

When using the terms 'capital' or 'investment' in the present context, the literatures from which I draw are referring to business or employer purchases of physical capital in the form of new technology or process innovations or investments in technological advances more broadly. The earliest analyses of technological change on the part of pluralist scholars of industrial relations in the U.S. came from Slichter and his colleagues (Slichter 1941; Slichter et al. 1960), whose examples ranged from 'the substitution of power-driven equipment for hand labour' to 'the use of automatic controls' and even-somewhat presciently-to 'the use of machines to replace the brain' (1960: 343). ${ }^{2}$

What Slichter et al. (1960: 350) refer to as 'outright and uncompromising opposition,' in which a union strikes over a proposed technological change or forbids its members from using the new equipment - essentially Luddism-would be the most direct way in which unions could forestall technological change. Possibly the most punctuated modern illustration of outright opposition to technological change came in the form of the 'Battle of Wapping,' during which News International CEO Rupert Murdoch successfully responded to unionists' steadfast opposition to the transition away from hot metal linotype to computerized typesetting by surreptitiously constructing a new plant in the London Docklands, far away from Britain's journalistic epicentre on Fleet Street. The result of that incident-zero lost days of production for Murdoch and the obliteration of over 5,000 union jobs (Henley 2011)-suggests why when considering their options in light of their absolute and relative degrees of bargaining power, unions might instead opt to encourage or to at least 'willingly accept' technological change with the intent to 'negotiate conditions favourable to the operation of the new equipment' (Slichter et al. 1960: 358). The specific 'conditions' labour might seek run the gamut from job security and guaranteed pay increases to rigid staffing rules surrounding the deployment and use of the new technology.

A widely-hailed, recent example of union negotiators' push for employment and wage security, in fact, comes from the very sector and the very technology on which this research focusesKaiser Permanente's deployment of its electronic health record system. In a series of collective bargaining agreements and in ad hoc effects bargaining, Kaiser, the largest managed healthcare provider in the U.S., promised 120,000 unionized workers employment and wage security and any necessary retraining in exchange for the union's commitment to optimizing the effectiveness of the new system (Kochan et al. 2009; Litwin 2011). 
Conversely, history offers numerous examples of labour unions negotiating the maintenance of inefficient production practices or suboptimal capital-labour ratios around the implementation of new technologies. Perhaps the most notorious was the eponymous practice of 'featherbedding,' in which the union representing railway firemen successfully negotiated the continued employment of their members even after the elimination coal-fired steam power. With the advent of diesel power, there was no longer a fire to be kept, allowing idle firemen to commandeer the sleeping car's unoccupied feathered mattresses intended, of course, for paying passengers (Litwin 2013; Murray 1998).

In either case, marginalists argue that these sorts of demands amount to an undue 'tax' levied solely against unionized employers' technology investments, rendering an identical, productivity-enhancing piece of capital less valuable to unionized employers than to nonunionized ones. Thus, while less direct than outright union opposition, the reality of what unions aim to do-protect their members' employment and the conditions thereof-would still be expected to dampen their employers' investment in new technologies.

As it turns out, even unions genuinely intending to encourage technological investment on the part of their employers can unwittingly deter it. Couching their work in Simons's (1944) notion that rent extraction should be the chief goal of those negotiating on behalf of the rankand-file, Baldwin (1983) and Grout (1984) separately offered game-theoretic models of the mechanisms by which unions could perhaps even inadvertently attenuate investment through collective bargaining. The more often-cited Grout model posits that even unions anticipating a high return through scale effects and thereby promising to moderate their wage demands subsequent to the firm's commitment to a large capital investment cannot make a credible and enforceable commitment to the low-wage course of action. Knowing this and understanding that union negotiators would have to face down worker pressures and their own strong temptation in a later period, the employer will choose to forego the investment in the present period. Baldwin's approach yields qualitatively identical results, though her intuition also depends on unions having a shorter time horizon and a higher discount rate than the firm's shareholders. In either case, the implication is that the collective bargaining process itself creates a holdup mechanism that will retard investments in new technologies. Connolly et al. (1986) provided initial empirical support for these rent-seeking theories, and more recently, Cardullo et al. (2015) substantiated and extended this line of thought by showing that the negative investment effects arising from union hold-up are especially acute in sunk cost-intensive sectors and firms. 
While this discussion of 'quasi-rents' and 'holdup' has been rooted in theory from outside of the field of industrial relations, these arguments, indeed, resonate with and echo from more institutionally-oriented scholars of work and employment. Freeman and Medoff (1984) and Hirsch (2004), for example, consider the impact of collective bargaining on investment largely through the lens of corporate profits. Both imply that when unions erode profitability through the appropriation of quasi-rents, they may be extracting surplus from retained earnings that would have been ploughed back into the company. Indeed, this reasoning provides an entirely separate avenue by which collective bargaining would inhibit investment in new technology (Metcalf 2003).

\section{Received Empirical Findings}

As Metcalf (2003: 150, emphasis in original) has stated, 'Studies of the impact of unionism on investment in the USA reach a remarkably consistent conclusion-a union presence reduces investment.' Much of the empirical work on which he relies to make this statement as well as evidence presented since comes from Hirsch (e.g., 1990; 1992; 1997; 2004), who sometimes finds double-digit percentage point effects of trade unions on investment rates. Some of this he attributes to the rent-seeking mechanisms outlined above while the rest he ascribes to the deleterious impact that unions have on profitability, and thus, the accumulation of surplus that can be reinvested in production.

Others have reached similar conclusions regarding the relationship between collective bargaining and capital investment in the U.S. (Becker and Olson 1992; Bronars et al. 1994; Cavanaugh 1998), some using clever econometric approaches to examine the impact of union certification elections (Fallick and Hassett 1999) and others undertaking rich qualitative analyses

of technology adoption in a single industry (Link and Siegel 2002). Keefe (1991) reveals negative union effects on investments in high-tech capital, in particular, and Bradley et al. (2016) find similar results in their regression-discontinuity approach to identifying the impact of collective bargaining on innovation.

In no way are these results limited to the U.S. Odgers and Betts (1997) also show doubledigit negative effects on investment resulting from the presence of unions in Canadian manufacturing industries similar to the industry-level effects identified by Denny and Nickell (1992) in the U.K. Others have shown the same to be true in a large-sample, cross-industry analysis of Australian establishments (Drago and Wooden 1994) and in a meta-regression 
analysis capturing firm- and industry-level data from the U.S., the U.K., Germany, and Canada (Doucouliagos and Laroche 2013). In sum, both theory and earlier empirical findings point to a negative, causal association between collective bargaining and investment.

\section{Data and Methods}

Data

Examining the relationship between $\mathrm{RN}$ unionism and the adoption of EHRs requires the construction of a dataset of hospital-years inclusive of measures of unionism, EHR adoption, and structural features of hospitals that could drive the adoption of EHR systems. Table 1 details the variables that comprise this effort. I use the American Hospital Association's (AHA) Annual Survey Database and Annual Survey Information Technology Supplement as the basis for the sample. According to the AHA, the annual response rate for the survey has never been less than $75 \%$. I construct the dependent variable-EHR adoption - in accordance with what has become the standard definition as to what constitutes a 'basic' hospital EHR system (e.g., Adler-Milstein et al. 2014; Adler-Milstein et al. 2015; DesRoches et al. 2013; DesRoches et al. 2012; Jha et al. 2011 ; Jha et al. 2009; Jha et al. 2010). That is, a hospital is counted as having at least a basic EHR system when it reports having, at minimum, full implementation of the following ten computerized functions in at least one clinical unit of the hospital: patient demographics, physician notes, nursing assessments, patient problem lists, patient medication lists, discharge summaries, laboratory reports, radiologic reports, diagnostic test results, and order entry for medications.

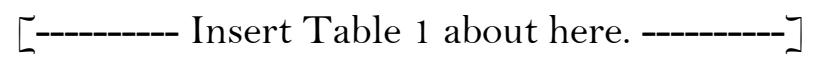

The AHA instrument also includes fine-grained questions regarding patient billing. This allows for the development of a measure of the share of patient-days billed to Medicare and Medicaid. These social welfare programs serve the elderly, the disabled, and the poor; they also reimburse hospitals at lower rates than do private insurance companies or those patients paying wholly out-of-pocket. Thus, a measure of the 'social welfare share' of the payer mix speaks to the nature of the patient population served by a hospital as well as to how well-resourced a hospital is.

The AHA questionnaire also seeks information allowing for the construction of key control variables. I measure the size of a hospital as the total number of beds set-up and staffed at the hospital at of the end of the reporting period. I construct a binary variable to capture whether 
or not a hospital is located in and serves an urban area based on whether or not a hospital's street address places it in a Core-Based Statistical Area (CBSA) of 'metropolitan' or larger as opposed to a CBSA defined as 'rural' or 'micropolitan.' I can also control for whether a hospital is a member of a hospital system as opposed to a fully independent operation.

Reliable data on union representation and union activity in the U.S. are surprisingly difficult to gather and construct (Dube et al. 2016; Ferguson 2008). A hospital website normally does not contain information on the union status of its workforce, and hospital administrators and their staffs usually refuse to answer any questions regarding worker representation from those outside the organization, particular for those hospitals that turn out not to have any unionized workers. Union locals are generally willing to provide clarifying information, but there is no single list of all of the union locals representing hospital workers. Thus, the best way to build such a database of nurse unionism is through systematic searches of court documents, periodicals, and where possible, contracts filed with regulatory agencies.

The private analytics firm Bloomberg/BNA follows these steps in its attempt to gather information on U.S. National Labour Relations Board elections, work stoppages, contract listings, unfair labour practices, and contract settlement summaries. While these data are somewhat inconsistent and incomplete, they provide the basis for the construction of the RN unionism measures. I combed through each of these databases to get a sense of which hospitals were unionized and which were not for each of the years 2008-2014. This often yielded anomalies that had to be researched and addressed individually. For example, when the scouring of the Bloomberg/BNA data implied a hospital's RNs were unionized over the period 2008-2010 and again from 2013-2014, I made a special effort to determine whether or not there was, indeed, a two to three-year gap in union representation. And, where the gap was determined to be erroneous, the data were, of course, corrected.

As difficult as it is to build a union representation database, it is even more challenging to glean any knowledge of precisely when a hospital unionized let alone of its attendant bargaining structures. As a result, I decided to constrain the study to hospitals in a single U.S. state. This allowed for the reliable determination of which hospitals did and did not bargain collectively with their RNs. It also made me comfortable ultimately treating hospitals' union status as constant within the seven-year observation period. With respect to bargaining structures, my understanding of the hospital sector in New York State dictated that estimates control for whether or not the hospital is a member of the League of Voluntary Hospitals and Homes of New 
York (LVHH or the League). The LVHH bargains as a group with the largest union local in the country, 1199SEIU, United Healthcare Workers East, yielding a multi-employer collective bargaining agreement that should not be treated as a series of coincidentally identical contracts.

Beyond boosting reliability and accounting for multi-employer bargaining, the decision to limit the analysis to New York provided two added benefits to the research design. First, it allowed for state regulatory consistency across all the hospitals under observation. Second, as New York has the highest union membership and union representation of any U.S. state, it guaranteed a substantial degree of variation in the key construct of interest. ${ }^{3}$ Thus, the initial sample captures 1,004 hospital years representing 193 distinct, non-federal, general acute care hospitals. With the addition of co-variates, the sample shrinks to 165 distinct hospitals spread over 827 hospital-years.

\section{Methods}

With a dataset of New York State hospital-years in hand, one can estimate two sets of models - one examining the state of hospital-level EHR adoption over the period 2008-2014 and a second highlighting whether and when a hospital adopts EHRs, conditional on the fact that it has not adopted the technology in a prior period - in each case, as a function of RN union status.

Strictly speaking, modelling the incidence or diffusion of EHRs over time, where EHR adoption is measured dichotomously, calls for multilevel logistic or probit regression (Wooldridge 2010). However, anticipating eventual analytical needs, I heed the advice of Ai and Norton (2003) and Long and Freese (2014), among others, who point to the use of the linear probability model for the ease with which it allows for the analysis of marginal effects associated with two-way multiplicative interaction terms. Accordingly, I will estimate a series of regression equations that allow for the isolation of the association between $\mathrm{RN}$ union status and EHR adoption by controlling for the aforementioned correlates of both. Aside from including the RN union indicator on the right-hand side (RHS), one can also partial out the effects of a hospital's size, location, system membership, and bargaining structures. Moreover, some of the models account for the effect of the share of patient days attributable to social welfare programs and allow me to differentiate the effect of this variable by a hospital's union status. I will also make use of a vector of year dummies as doing so allows for the parameterization of time in the most general and least restrictive way possible (Singer and Willett 2003) while capturing the trending increase in adoption probabilities over time (Rogers 2003). 
Answering the 'whether and when' question requires the estimation of an analogous set of discrete-time, exponential hazard models using the same RHS variables outlined above. The principal distinction between the linear probability models and the hazard models is nontrivial: while the regressions assess the probability of a hospital reporting the presence of EHRs in a given year, the hazard models treat adoption as a 'terminal' or 'absorbing' event and thus, report the likelihood of a hospital's initial adoption of an EHR system in a given year conditional on the fact that a hospital had not yet adopted the technology (Allison 1984; Singer and Willett 2003). Accordingly, the hazard estimates add more nuance to our understanding of the relationship between the union status of a hospital's nurses and its inclination towards the transition away from conventional, paper health records.

\section{Results}

\section{Descriptive Statistics}

Table 2 shows the means, standard deviations, and pairwise correlations for the sample of hospital-years called upon in the study. Note that $36 \%$ of the hospital-years in the sample meet the threshold for having at least a basic EHR system in-place and half of the hospital-years have a unionized, $\mathrm{RN}$ workforce. Nearly $3 / 4$ of patient days are funded by social welfare programs as opposed to private insurance, and almost $1 / 5$ of the sample is part of the LVHH, the multiemployer body that negotiates and administers labour agreements with 1199SEIU, United Healthcare Workers East. That so large a portion of the sample bargains on a centralized, multiemployer basis underlines the need for researchers to account for bargaining structures in analyses like this one. The average size of hospitals in the sample is 344 beds, with a great deal of variation about the mean. Almost $4 / 5$ of the hospital-years satisfy the definition of urban, and half report being part of a hospital system.

\section{[---------- Insert Table 2 about here. ----------]}

Interestingly, none of the variables shows a strong pairwise association with the technology measure. The RN union dummy reveals only a very weak, positive correlation with EHR adoption. It is also positively pairwise correlated with League membership, which is not surprising. Beyond that, there is evidence that urban hospitals and those that are part of the multi-employer bargaining group are, on average, larger in size than other hospitals.

\footnotetext{
[--------- Insert Figure 3 about here. ----------]
} 
As noted above, the pairwise correlation between EHR adoption and RN unionism in Table 2 suggests a positive albeit negligible association between these two constructs, at least in a dataset of hospital-years. However, since these are both binary variables, it makes more sense to examine this relationship graphically and longitudinally as presented in Figure 3. Panel (a.) essentially recasts Figure 1, but does so for the single-state sample as opposed to a national one. And, it shows that New York State adoption has roughly paralleled that of the nation as a whole. That is, EHR use increases monotonically according to something of a quadratic trend. Panel (b.) partitions the data series into separate ones for nonunion and unionized hospitals. It reveals that without controlling for any covariates, unionized and nonunion hospitals reported very similar adoption levels in the initial and final years of observation. However, in the intermediate years, the union growth curve is steeper than the nonunion one, implying that unionized hospitals may have been slightly faster in their transition to EHRs than were nonunion hospitals.

\section{Panel and Hazard Estimates}

In order to account for the other factors that drive EHR incidence and that themselves likely correlate with RN unionism, I turn to the multilevel linear probability estimates shown in Table 3. The table reports coefficients, $\boldsymbol{z}$-statistics, and statistical significance levels predicated on standard errors clustered at the hospital level. Model 1 includes only the time dummies, where the first year of observation, 2008, serves as the referent category. In this case, save for the dummy representing 2009, each of the coefficients on the year indicators is positive and statistically significant, and in fact, larger than the previous year's coefficient. To clarify, a

positive coefficient estimate, $\hat{\beta}>0$, implies that a single-unit increase in that independent variable boosts the probability of EHR adoption by the amount $\hat{\beta}$. Taking the coefficient on the year 2010 dummy in Model 1 as an illustration, holding all other variables constant, a hospital was $\hat{\beta} \approx .08$ or eight percent more likely to report EHR use in 2010 than it was in 2008. Based on the pattern and precision of estimates in Model 1, one can safely infer that adoption rates were increasing monotonically beginning in 2010.

\section{[-------- Insert Table 3 about here. ---------]}

Model 2 adds only a single covariate to capture RN unionism. Not only does this variable enter with an insignificant point estimate, but its inclusion has no discernible effect on the impact of the time dummies. This implies that there is no simple, incremental, time-invariant, or unconditional effect of $\mathrm{RN}$ unionism on the likelihood that a hospital reports using at least a basic 
EHR system. Model 3 increments upon Model 2 by adding a vector of two-way, multiplicative interaction terms between the year and union dummies. While these estimates are not shown on the table, suffice it to say that none of them even approach conventional levels of statistical significance. Collectively, the statistical insignificance of these six estimates as well as the insignificance of the coefficient on the linear effect of $\mathrm{RN}$ unionism imply that in the absence of control variables, union and nonunion hospitals share a common intercept and temporal adoption trajectory.

The fourth model adds the aforementioned control variables — size, location, health system membership, League membership, and most importantly, the social welfare share of the payer mix. Note that each $\log$ point increase in size increases the probability of EHR adoption by about .07 , not surprising given the fixed cost nature of an EHR implementation. Likewise, Model 4 reveals a precisely-estimated, negative point estimate for the social welfare term. Controlling for the other variables, those hospitals serving a larger share of less lucrative elderly, disabled, and indigent patients are less likely to have transitioned from conventional, paper-based records to an EHR system. While this may not be surprising, it is telling: hospitals that are less wellresourced are slower adopters. To the extent that one accepts arguments regarding the returns to care quality arising from the use of EHRs, he or she must also accept that the most needy patients are not availed of these benefits.

Note that in Model 4, the linear effect of $\mathrm{RN}$ unionism remains insignificantly different from zero, suggesting that $\mathrm{RN}$ unions are, at best, innocuous with respect to EHR investment. However, Model 4 constrains the impact of the unionism dummy to be unconditional on a hospital's payer mix. In other words, one cannot establish from the estimates in Model 4 whether or not nurses' unions influence the technology adoption decision the same way for hospitals serving disadvantaged patients as they do for hospitals that are better-resourced.

Model 5 takes up this question by adding one more variable to the RHS-an interaction term to capture the impact of $\mathrm{RN}$ unionism on EHR adoption conditional on the social welfare share of a hospital's payer mix. In this case, the magnitude of the negative estimate on the linear effect of the welfare share increases as does its precision. Likewise, the estimate on the union term turns negative and significant. However, the estimate on the interaction term is positive and significant at the .001 level. Collectively, these estimates imply that for hospitals serving the most lucrative patients, i.e., those with a welfare share closer to zero, RN unions, are indeed, associated with a lower likelihood of EHR adoption. Likewise, in nonunion hospitals, increases 
in the welfare share are associated with a decreased likelihood of EHR adoption. However, the opposite appears to be true in hospitals that bargain collectively with their nurses. In these hospitals, increased service to an elderly, disabled, or indigent patient population is associated with an increased probability of EHR adoption. In fact, at the sample mean and median levels of the social welfare share variable, EHR adoption probability is about seven percentage points higher for unionized than for nonunion hospitals.

[-------- Insert Table 4 about here. ----------

Before detailing graphically the lessons learned from the linear probability estimates of EHR adoption, I will briefly consider the analogous set of exponential hazard estimates undertaken on a dataset of 'spells' in which EHR adoption is treated as a terminal event. Recall that the structure of the spells data allows one to use the same variables to predict not only whether a hospital adopts EHRs, but when, conditional on the fact that it has not adopted the technology in a prior period. Moving across the models and building up to Model 5, one can see the dynamics of adoption revealed by these estimates are quite similar to those in Table 3 . Thus, we can conclude that the only precisely-estimated negative investment effects associated with $\mathrm{RN}$ unionism emerge only after allowing the union effect to be conditional on a hospital's payer mix. And, once again, we see that unions only appear to erode health IT investment for the most wellresourced hospitals. As the share of a hospital's payer mix shifts from lucrative private insurance and more toward government-funded social welfare programs, the union effect reverses such that collective bargaining becomes a positive driver of technology investment. ${ }^{4}$

\section{[------- Insert Figure 4 about here. --------]}

Given the opacity of partial slopes on interaction terms, the most straightforward way to derive meaning from the estimates is to plot the fitted values that emerge from them. Towards that end, panels (a.) and (b.) in Figure 4 are derived from Model 5 in Table 3. Each displays fitted probabilities of a hospital's adoption of at least a basic EHR system each year, separately for those hospitals that do and do not bargain collectively with their nurses. In panel $(a$.), the social welfare share is arbitrarily held at .2 while all of the other covariates (aside from the year dummies) are held at their sample means. Note that while the likelihood of investment increases in time for both union and nonunion hospitals, the latter are always significantly more likely to report at least a basic EHR system being in place. In fact, by 2014, a prototypical hospital that does not bargain collectively with its nurses and reports that 80 percent of its patient days are covered by private insurance or cash-paying patients has a predicted probability of adoption in excess of 
1.00. ${ }^{5}$ In panel (b.), the only assumption that differs is the value of the social welfare share. When it is set at .9-implying that 90 percent of patient days are financed by Medicare or Medicaidthe location of the two fitted data series flips. In this case, unionized hospitals are always more likely than nonunion ones to report EHR investment. Under this scenario, by 2014, unionized hospitals were 82 percent likely to report the use of at least a basic EHR system, whereas nonunion hospitals were just 60 percent likely to do the same.

The remaining two panels in Figure $4,(c$.$) and (d$.$) , are somewhat analogous to panels (a$.$) and$ (b.). However, the data series illustrated are median log survival times-or, in the language of the natural sciences, 'half-lives' - fitted from Model 5 in Table 4. Panel (c.) once again holds the social welfare share at .2. What we see is that log survival times-fitted time to adoption conditional on non-EHR adoption up until that point - are declining in time, but always greater for unionized than for nonunion hospitals. The relative locations of the two curves switch in panel $(d$.$) , where the social welfare share has been adjusted upward to .9. For those hospitals$ whose payer mix is titled heavily toward the poor, disabled, and elderly, unionized hospitals are always more inclined toward EHR investments than nonunion hospitals. In fact, by the final year, the model suggests that unionized hospitals will not even 'survive', i.e., remain as nonadopters, through the end of the current year.

\section{Discussion}

The finding that nurses' unions did not have a dampening effect on U.S. hospital EHR adoption cuts against the grain of received theory and research. As such, it implies that the aforetheorized mechanisms yielding a negative association between unionism and investment are being offset by processes in which $\mathrm{RN}$ unions promote or at least allow for the transition away from paper-based recordkeeping.

One potential explanation comes from fieldwork and others' mixed-method research. Completely apart from any economic argument, nurses famously prioritize patient care over and above organizational and even occupational and union objectives when these objectives conflict (Clark and Clark 2006). Thus, aside from the more economic arguments to follow, the positive relationship that one sees in these data could arise from a belief amongst nurses and their unions that improved recordkeeping could facilitate the coordination and delivery of patient care in a way that redounds first and foremost to the patients they serve. Clearly, this determination 
would generate a positive relationship between $\mathrm{RN}$ unionism and $\mathrm{EHR}$ investment, thereby countering the negative effects predicted by previous research.

Having noted that, one can also explain the present findings by revisiting the economic theory on which many of the predictions of a negative association are predicated. It largely assumes bargaining between labour and management can be described by the so-called 'right-to-manage' (RTM) or 'monopoly union’ models. Under these models, the parties negotiate solely over wages, allowing employment levels to be set by an exogenous demand schedule. Since it was first pointed out by Leontief (1946), labour economists have accepted and students have been taught that these 'on the demand curve' settlements are economically inefficient (e.g., Cahuc et al. 2014; Ehrenberg and Smith 2015). The 'efficient bargaining' or 'efficient contracts' model, in which labour and management bargain simultaneously over both wages and employment levels serves as a Pareto-efficient alternative to the RTM model. Indeed, Menezes-Filho, Ulph, and Van Reenen's (1998: 57, emphasis added) extension of the Grout (1984) model reveals that union power will always depress $\mathrm{R} \& \mathrm{D}$ if the union bargains only over the wage. It is only when unions bargain over employment that the relationship between union power and $\mathrm{R} \& \mathrm{D}$ could be positive.

Grout himself suggested that labour and management could forestall the negative consequences arising from his framework were they willing to go one step further by bargaining over the investments themselves (Menezes-Filho and Van Reenen 2003). Yet, as the same researchers point out, explicit bargaining over employment levels occurs only rarely, and 'bargaining over the introduction of new technology or investment is still rarer' (297).

Nonetheless, in the U.S., in particular, management has the legal right to unilaterally refuse to bargain over issues related to technology and investment, as these subjects are considered 'permissible' but not 'mandatory' subjects of bargaining. Thus, one can infer the existence of a high-quality, cooperative labour-management relationship when the parties' initiate their negotiations by agreeing to broaden the scope of bargaining. Likewise, given its ongoing nature and open-endedness, labour relations scholars and practitioners have long recognized the value of trust in the administration of the employment relationship (Commons 1931). When one views Grout's (1984) model through this lens, they see that he wrongly assumes the employment relationship and the labour negotiation that takes place within it to be a one-shot or endgame bargain, essentially ignoring Walton and McKersie's (1965) ground-breaking work on attitudinal structuring. If, on the other hand, unions care about their longer term ability to 
maintain a constructive and productive relationship with their management counterparts, then this once-off game becomes a repeated game in which both sides have an incentive to maintain positive relations and not to damage the economic health of their counterparts at the bargaining table (Van der Ploeg 1987).

Freeman and Medoff (1984) would broaden this notion of labour-management cooperation even further by noting that in healthy labour-management relationships, unions succeed in constructively channelling worker discontent in a way that curbs turnover, encourages investment in firm-specific human capital, and improves morale, all of which could serve to make identical technology more productive in a unionized workplace than in an otherwise identical nonunion one. Similarly, nurses' unions may appreciate and value the "free" training-employer investments in a form of general human capital — attendant to the implementation and use of popular EHR systems. ${ }^{6}$ Empirical research has shown these dynamics yield a positive relationship between collective bargaining and investment in Japan, where its enterprise unions typically maintain longstanding, rich, and cooperative relations with the enterprises to which they are matched (Benson 1994). Closer to the present research context and as noted earlier, the U.S. healthcare provider Kaiser Permanente has broadened the scope of its bargaining to include employment, staffing levels, and investment, among many other topics, and it, too, provides an example counter to the predictions of negative union effects on investment (Kochan et al. 2009; Litwin 2011; Litwin and Eaton forthcoming).

In light of the high-skilled nature of $\mathrm{RN}$ labour, one can also envisage a mechanism by which the economic self-interest of nurses and their unions could actually promote health IT investment. Research on the ways that labour and IT coalesce in production has determined that just as computers tend to displace lower-skilled labour, they also tend to complement the productivity of and therefore to increase the demand for more highly-skilled workers (e.g., Bresnahan et al. 2000; Bresnahan et al. 2002; Krueger 1993). Researchers brand this phenomenon skill-biased technological change (SBTC). It is not difficult to see how these dynamics could obtain with respect to EHRs: to the extent that EHRs facilitate the automation of routine, codifiable tasks (Autor et al. 2002; Autor et al. 2003), they will displace lower-skilled licensed practical/vocational nurses (LP/VNs), certified nursing assistants (CNAs), or medical assistants (MAs). ${ }^{7}$ Each of these jobs falls below RNs in the hospital skills hierarchy and has evolved to relieve RNs of responsibilities that could instead be undertaken by this lower-paid labour. 
As a result of this partial substitutability, these job classifications often-but not alwaysbargain as one. In some instances, RNs bargain separately from LPNs, CNAs, and MAs. Consequently, to the extent that this SBTC argument helps explain the anomalous result that I find with respect to unions and technology investment, it should only hold for RN-exclusive bargaining units. In fact, the nature of and variation across bargaining structures in New York State allows for an explicit test of this theory. The largest representative of RNs in the state is the New York State Nurses Association (NYSNA), a union whose locals are comprised entirely of RNs and, in some cases, more highly-skilled clinical nurse specialists, nurse anaesthetists, nurse midwives, and nurse practitioners as well. Thus, to the extent one can identify NYSNA union locals in the sample and distinguish them from other local unions, one can separate RNexclusive locals ${ }^{8}$ from locals that include $\mathrm{RNs}$ among other, lesser-skilled job classes. By essentially re-running the analysis with these two separate union types, one can determine whether the previous results are driven by $\mathrm{RN}$-exclusive bargaining units, and thus, consistent with an SBTC argument that should then inform received theory linking unions to investment.

\section{[------- Insert Table 5 about here. -------]}

The fruits of this exercise are displayed in Table 5. Models 1-3 are multilevel linear probability models akin to those presented in Table 3 while Models 4-6 are exponential discretetime hazard models like those appearing in Table 4. The difference is in the operationalization of RN unionism: instead of using a single binary variable, I now employ one for hospitals with $\mathrm{RNs}$ in a mixed bargaining unit and another for hospitals that bargain with an RN-exclusive union local. Nonunion hospitals remain the referent category. I also interacted each of these variables with the variable measuring the social welfare share of the hospital's payer mix.

Analysis of the first three models makes clear that the dynamics observed earlier-nurses' unions dampening investment only for those hospitals with a trifling welfare share, but bolstering adoption for less well-resourced hospitals—obtain only for RN-exclusive bargaining units. Conversely, the main and interaction effects associated with mixed bargaining units are both insignificant. The second three columns of estimates replicate these relationships, but in the discrete-time hazard framework. In the net, Models 3 and 6 provide strong evidence that nurses' unions may well be urging hospitals to make these investments-particularly those hospitals that might otherwise not find it economically sensible to do so-because they are themselves likely to benefit economically from them as well. More generally, they inject two critical contingencies into existing theory tying collective bargaining to investment. That is, to 
what extent is the capital in question skill-biased? And, do incumbent bargaining structures allow unions to promote investment in this technological capital?

Unfortunately, while the examination of bargaining structures helped flesh out this skillscomplementarity argument, it is also consistent with the earlier argument that nurses and their unions may well favour EHR adoptions on care quality and patient safety grounds. After all, to the extent that RNs might push their union leaders to bargain for technological investment, they are more likely to rule the day in an RN-exclusive bargaining unit than in a mixed bargaining unit in which they will assuredly make up a minority of the rank-and-file.

\section{Conclusion}

Despite the heavy weight of existing theory and research, I find little evidence to suggest that those hospitals that bargain collectively with their RN workforces are systematically less likely or slower to transition from paper-based to electronic health records. In fact, nurse unionism is positively associated with EHR adoption for those hospitals serving the median share of elderly, disabled, and indigent patients. Furthermore, the positive health IT investment effects associated with $\mathrm{RN}$ unionism actually strengthen as the welfare share of a hospital's payer mix increases beyond the median. This finding implies that these unions succeed in 'shocking' hospital administration out of its complacency with paper-based recordkeeping, particularly to the extent that this complacency was linked to hospitals' reliance on a steady stream of less lucrative welfare patients. Consequently, these findings point to a heretofore undetected mechanism by which nurses' unions augment social welfare.

Admittedly, there may well be fundamental differences between those hospitals that do and do not bargain collectively with their nurses. Furthermore, that technological change qualifies as a 'permissible' or 'voluntary' subject of bargaining as opposed to a 'mandatory' or 'prohibited' one further leaves open the possibility that unobserved heterogeneity partially drives the results. That is, I do not know the extent to which nurses' unions are actually bargaining over employment or effort levels let alone directly over EHR investment at each of the hospitals under study. Thus, while it may not be feasible, one way to bolster these findings would be to observe bargaining directly to determine the extent to which issues around health IT and EHRs are negotiated over, as theory suggests that doing so explicitly (McDonald and Solow 1981) or even implicitly (Johnson 1990) would engender a positive association between the incidence of collective bargaining and investments in new technologies. As I point out above, the willingness 
of unions and their employers to bargain over these issues, which would be indicative of a cooperative labour-management relationship, would be expected to invert the sign on the predicted relationship between unions and investment. Thus, the presence of such bargaining relationships in the study sample could be countering the negative association called for by existing theory and research, which itself is predicated on conventional, adversarial collective bargaining relationships that typified an earlier era.

\section{REFERENCES}

Adler-Milstein, J., DesRoches, C. M., Furukawa, M. F., Worzala, C., Charles, D., Kralovec, P. and Stalley, S. (2014). 'More Than Half of U.S. Hospitals Have at Least a Basic EHR, But Stage 2 Criteria Remain Challenging for Most.' Health Affairs, 33(9): 1664-1671.

Adler-Milstein, J., DesRoches, C. M., Kralovec, P., Foster, G., Worzala, C., Charles, D., Searcy, T. and Jha, A. K. (2015). 'Electronic Health Record Adoption in U.S. Hospitals: Progress Continues, But Challenges Persist.' Health Affairs, 34(12): 2174-2180.

Ai, C. and Norton, E. C. (2003). 'Interaction Terms in Logit and Probit Models.' Economics Letters, 80(1): 123-129.

Aldrich, J. H. and Nelson, F. D. (1984). Linear Probability, Logit, and Probit Models. Beverly Hills: Sage.

Allison, P. D. (1984). Event History Analysis: Regression for Longitudinal Event Data. Beverly Hills: Sage.

Autor, D. H., Levy, F. and Murnane, R. J. (2002). 'Upstairs, Downstairs: Computers and Skills on Two Floors of a Large Bank.' Industrial and Labor Relations Review, 55(3): 432-447.

Autor, D. H., Levy, F. and Murnane, R. J. (2003). 'The Skill Content of Recent Technological Change: An Empirical Investigation.' Quarterly Journal of Economics, 118(4): 1279-1333.

Avgar, A. C., Eaton, A. E., Givan, R. K. and Litwin, A. S. (2016). 'Editorial Essay: Introduction to a Special Issue on Work and Employment Relations in Health Care.' Industrial and Labor Relations Review, 69(4): 787-802.

Baldwin, C. Y. (1983). 'Productivity and Labor Unions: An Application of the Theory of Self- Enforcing Contracts.' Journal of Business, 56(2): 155-185.

Becker, B. E. and Olson, C. A. (1992). 'Unions and Firm Profits.' Industrial Relations, 31(3): 395-415.

Benson, J. (1994). 'The Economic Effects of Unionism on Japanese Manufacturing Enterprises.' British Journal of Industrial Relations, 32(1): 1-21.

Bloomberg/BNA (2015). 'Unions and the Health Care Industry: Trends in Organizing and Bargaining 2014.' Bloomberg/BNA Legal Highlights.

Bradley, D., Kim, I. and Tian, X. (2016). 'Do Unions Affect Innovation?’ Management Science: in-press.

Bresnahan, T. F., Brynjolfsson, E. and Hitt, L. M. (2000). 'Technology, Organization, and the Demand for Skilled Labor.' In M. M. Blair and T. A. Kochan (eds.), The New Relationship: Human Capital in the American Corporation. Washington, DC: Brookings, pp. 145-184.

Bresnahan, T. F., Brynjolfsson, E. and Hitt, L. M. (2002). 'Information Technology, Workplace Organization, and the Demand for Skilled Labor: Firm Level Evidence.' Quarterly Journal of Economics, 117(1): 339-376. 
Bronars, S. G., Deere, D. R. and Tracy, J. S. (1994). 'The Effects of Unions on Firm Behavior: An Empirical Analysis Using Firm-Level Data.' Industrial Relations, 33(4): 426-451.

Cahuc, P., Carcillo, S. and Zylberberg, A. (2014). Labor Economics (2 ${ }^{\text {nd }}$ ed.). Cambridge, MA: MIT.

Cardullo, G., Conti, M. and Sulis, G. (2015). 'Sunk Capital, Unions and the Hold-Up Problem: Theory and Evidence from Cross-Country Sectoral Data.' European Economic Review, 76: 253-274.

Cavanaugh, J. K. (1998). 'Asset-Specific Investment and Unionized Labor.' Industrial Relations, 37(1): 35-50.

Clark, P. F. (2013). 'Health Care: Collective Bargaining's Growing Role in a Time of Transition.' In H. R. Stanger, P. F. Clark and A. C. Frost (eds.), Collective Bargaining under Duress: Case Studies of Major North American Industries. Urbana-Champaign: Labor and Employment Relations Association, pp. 119-163.

Clark, P. F. and Clark, D. A. (2006). 'Union Strategies for Improving Patient Care: The Key to Nurse Unionism.' Labor Studies Journal, 31(1): 51-70.

CMS (2015). National Health Expenditure Fact Sheet. U.S. Centers for Medicare and Medicaid Services, Baltimore.

Commons, J. R. (1909). 'American Shoemakers, 1648-1895: A Sketch of Industrial Evolution.' Quarterly Journal of Economics, 24(1): 39-98.

Commons, J. R. (1931). 'Institutional Economics.' American Economic Review, 2 1(4): 648-657.

Connolly, R. A., Hirsch, B. T. and Hirschey, M. (1986). 'Union Rent Seeking, Intangible Capital, and Market Value of the Firm.' Review of Economics and Statistics, 68(4): 567-577.

Denny, K. and Nickell, S. J. (1992). 'Unions and Investment in British Industry.' The Economic Journal, 102(413): 874-887.

DesRoches, C. M., Charles, D., Furukawa, M. F., Joshi, M. S., Kralovec, P., Mostashari, F., Worzala, C. and Jha, A. K. (2013). 'Adoption of Electronic Health Records Grows Rapidly, But Fewer Than Half of U.S. Hospitals Had At Least a Basic System in 2012.' Health Affairs: 10.1377/hlthaff. 2013.0308.

DesRoches, C. M., Worzala, C., Joshi, M. S., Kralovec, P. D. and Jha, A. K. (2012). 'Small, Nonteaching, and Rural Hospitals Continue to Be Slow in Adopting Electronic Health Record Systems.' Health Affairs, 31(5): 1092-1099.

Doucouliagos, H. and Laroche, P. (2013). 'Unions and Innovation: New Insights from the Cross-Country Evidence.' Industrial Relations, 52(2): 467-491.

Drago, R. and Wooden, M. (1994). 'Unions, Innovation and Investment: Australian Evidence.' Applied Economics, 26(6): 609-615.

Dube, A., Kaplan, E. and Thompson, O. (2016). 'Nurse Unions and Patient Outcomes.' Industrial and Labor Relations Review, 69(4): 803-833.

Ehrenberg, R. G. and Smith, R. S. (2015). Modern Labor Economics: Theory and Public Policy (12 $2^{\text {th }}$ ed.). Boston: Pearson.

Fallick, B. C. and Hassett, K. A. (1999). 'Investment and Union Certification.' Journal of labor Economics, 17(3): 570582 .

Ferguson, J.-P. (2008). 'The Eyes of the Needles: A Sequential Model of Union Organizing Drives, 1999-2004.' Industrial and Labor Relations Review, 62(1): 3-21.

Freeman, R. B. and Medoff, J. L. (1984). What Do Unions Do? New York: Basic Books. 
Grout, P. A. (1984). 'Investment and Wages in the Absence of Binding Contracts: A Nash Bargaining Approach.' Econometrica, 52(2): 449-460.

Henley, J. (2011). 'Rupert Murdoch and the Battle of Wapping: 25 Years On.' The Guardian, July $27^{\text {th }}$.

Hirsch, B. T. (1990). 'Innovative Activity, Productivity Growth, and Firm Performance: Are Labor Unions a Spur or a Deterrent?’ Advances in Applied Micro-Economics, 5: 69-104.

Hirsch, B. T. (1992). 'Firm Investment Behavior and Collective Bargaining Strategy.' Industrial Relations, 31(1): 95121.

Hirsch, B. T. (1997). Unionization and Economic Performance: Evidence on Productivity, Profits, Investment and Growth. Vancouver: Fraser Institute.

Hirsch, B. T. (2004). 'What Do Unions Do for Economic Performance?’ Journal of Labor Research, 25(3): 415-455.

Hirsch, B. T. and Macpherson, D. A. (2016). Union Membership and Earnings Data Book: Compilations from the Current Population Survey. Washington: Bureau of National Affairs.

Jha, A. K., Burke, M. F., DesRoches, C., Joshi, M. S., Kralovec, P. D., Campbell, E. G. and Buntin, M. B. (2011). 'Progress Toward Meaningful Use: Hospitals' Adoption of Electronic Health Records.' American Journal of Managed Care, 17 (special issue): sp117-sp124.

Jha, A. K., DesRoches, C. M., Campbell, E. G., Donelan, K., Rao, S. R., Ferris, T. G., Shields, A., Rosenbaum, S. and Blumenthal, D. (2009). 'Use of Electronic Health Records in U.S. Hospitals.' New England Journal of Medicine, 360(16): 1628-1638.

Jha, A. K., DesRoches, C. M., Kralovec, P. D. and Joshi, M. S. (2010). 'A Progress Report on Electronic Health Records in U.S. Hospitals.' Health Affairs, 29(10): 1951-1957.

Johnson, G. E. (1990). 'Work Rules, Featherbedding, and Pareto-Optimal Union-Management Bargaining.' Journal of Labor Economics, 8(2): S237-S259.

Juraschek, S. P., Zhang, X., Ranganathan, V. and Lin, V. W. (2012). 'United States Registered Nurse Workforce Report Card and Shortage Forecast.' American Journal of Medical Quality, 27(3): 241-249.

Kangas, S., Kee, C. C. and McKee-Waddle, R. (1999). 'Organizational Factors, Nurses' Job Satisfaction, and Patient Satisfaction with Nursing Care.' Journal of Nursing Administration, 29(1): 32-42.

Keefe, J. H. (1991). 'Do Unions Influence the Diffusion of Technology?' Industrial and Labor Relations Review, 44(2): 261-274.

Kochan, T. A., Eaton, A. E., McKersie, R. B. and Adler, P. S. (2009). Healing Together: The Labor-Management Partnership at Kaiser Permanente. Ithaca: Cornell/ILR.

Krueger, A. B. (1993). 'How Computers Have Changed the Wage Structure: Evidence from Microdata.' Quarterly Journal of Economics, 108(1): 33-60.

Leontief, W. (1946). 'The Pure Theory of the Guaranteed Annual Wage Contract.' Journal of Political Economy, 54(1): 76-79.

Link, A. N. and Siegel, D. S. (2002). 'Unions and Technology Adoption: A Qualitative Analysis of the Use Of RealTime Control Systems in U.S. Coal Firms.' Journal of Labor Research, 23(4): 615-630.

Littlejohn, L., Campbell, J., Collins-McNeil, J. and Khayiled, T. (2012). 'Comparative Analysis of Nursing Shortage.' International Journal of Nursing, 1(1). 
Litwin, A. S. (2011). 'Technological Change at Work: The Impact of Employee Involvement on the Effectiveness of Health Information Technology.' Industrial and Labor Relations Review, 64(5): 863-888.

Litwin, A. S. (2013). 'Not Featherbedding, but Feathering the Nest: Human Resource Management and Investments in Information Technology.' Industrial Relations, 52(1): 22-52.

Litwin, A. S., Avgar, A. C. and Becker, E. R. (2017). 'Superbugs vs. Outsourced Cleaners: Employment Arrangements and the Spread of Healthcare-Associated Infections.' Industrial and Labor Relations Review, 70(3): 610-641.

Litwin, A. S. and Eaton, A. E. (forthcoming). 'Complementary or Conflictual? Formal Participation, Informal Participation, and Organizational Performance.' Human Resource Management: in-press.

Long, J. S. and Freese, J. A. P. Y. (2014). Regression Models for Categorical Dependent Variables Using Stata (3 ${ }^{\text {rd }}$ ed.). College Station: Stata.

McDonald, I. M. and Solow, R. M. (1981). 'Wage Bargaining and Employment.' American Economic Review, $71(5)$ : 896-908.

Menezes-Filho, N., Ulph, D. and Van Reenen, J. (1998). 'R\&D and Unionism: Comparative Evidence from British Companies and Establishments.' Industrial and Labor Relations Review, 52(1): 45-63.

Menezes-Filho, N. and Van Reenen, J. (2003). 'Unions and Innovation: A Survey of the Theory and Empirical Evidence.' In J. T. Addison and C. Schnabel (eds.), International Handbook of Trade Unions. Northampton, MA: Edward Elgar, pp. 293-334.

Metcalf, D. (2003). 'Unions and Productivity, Financial Performance and Investment: International Evidence.' In J. T. Addison and C. Schnabel (eds.), International Handbook of Trade Unions. Northampton, MA: Edward Elgar, pp. $118-171$.

Murray, R. E. (1998). The Lexicon of Labor. New York: New Press.

Odgers, C. W. and Betts, J. R. (1997). 'Do Unions Reduce Investment? Evidence from Canada.' Industrial and Labor Relations Review, 51(1): 18-36.

Porter, M. E. and Teisberg, E. O. (2006). Redefining Health Care: Creating Value-Based Competition on Results. Boston: Harvard Business School.

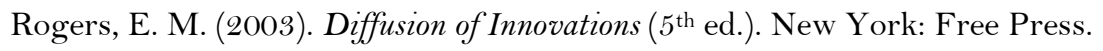

Simons, H. C. (1944). ‘Some Reflections on Syndicalism.’ Journal of Political Economy, 52(1): 1-25.

Singer, J. D. and Willett, J. B. (2003). Applied Longitudinal Data Analysis: Modeling Change and Event Occurrence. New York: Oxford.

Slichter, S. H. (1941). Union Policies and Industrial Management. Washington, DC: Brookings.

Slichter, S. H., Healy, J. J. and Livernash, E. R. (1960). The Impact of Collective Bargaining on Management. Washington, DC: Brookings.

Snavely, T. M. (2016). 'A Brief Economic Analysis of the Looming Nursing Shortage in the United States.' Nursing Economics, 34(2): 98-100.

Van der Ploeg, F. (1987). 'Trade Unions, Investment, and Employment: A Non-Cooperative Approach.' European Economic Review, 31(7): 1465-1492. 
Walton, R. E. and McKersie, R. B. (1965). A Behavioral Theory of Labor Negotiations: An Analysis of a Social Interaction System. New York: McGraw-Hill.

Wooldridge, J. M. (2010). Econometric Analysis of Cross-Section and Panel Data (2nd ed.). Cambridge, MA: MIT.

\footnotetext{
${ }^{1}$ Throughout this paper, I employ the terms EHR 'investment,' 'adoption,' and 'use' interchangeably. Were this an analysis linking EHRs to performance outcomes, this diction would be problematic, as purchasing technology does not ensure organizations have implemented it or that frontline workers are using it. As it stands, using these words allows me to bridge the writing of economists, who speak of investment, with that of labour relations and organizational scholars who approach the same phenomenon in terms of adoption or use.

${ }^{2}$ Though some point to Commons's (1909) case study of shoemakers as the initial pluralist industrial relations foray into technological impact, Commons actually excluded 'technical "instruments of production" (48) from his assessment of the drivers of workers' desire for protective organizations.

${ }^{3}$ One potential downside to limiting the sample to a single state-New York, in particular-is that doing so precludes controlling for whether or not a hospital operates as a for-profit or as a non-profit entity. This is because the state of New York actually explicitly bars market entry of for-profit hospitals, making it one of four U.S. states that have no such facilities in operation. Nonetheless, recent research by Litwin et al. (2017) shows that in a sample of California hospitals, for-profit status is uncorrelated with employment arrangements. Furthermore, in only two states - Florida and Nevada - do for-profit hospitals account for a majority of those in operation. And, in some states, fewer than two percent of hospitals are designated as for-profit.

${ }^{4}$ I re-estimated Models 4 and 5 in Table 3 as well as Models 4 and 5 in Table 4 using an alternative operationalization of the social welfare measure that captures "charity care" in addition to care provided under the auspices of Medicare and Medicaid. The results of these alternative estimates, available from the author, are marginally stronger than the ones presented in the paper. I thank an anonymous reviewer for suggesting this alternative operationalization as a robustness check.

${ }^{5}$ Recall that the focus on the marginal effects of a two-way, multiplicative interaction term necessitated my use of a linear probability model in place of a nonlinear specification intended for the estimation of limited dependent variables. This predicted probability outside the $[0,1]$ range is a consequence of this decision (Aldrich and Nelson 1984).

${ }^{6}$ I thank an anonymous reviewer for suggesting this point.

${ }^{7}$ U.K. analogues for these three roles include enrolled nurses (ENs) and care assistants.

8 These bargaining units are not truly $\mathrm{RN}$-exclusive since they can include even more highly-skilled, specialized nursing occupations as well.
} 
TABLE 1

Variable Definitions, Construction, and Sources

\begin{tabular}{|c|c|c|c|}
\hline Variable & Definition/Survey Item(s) & Construction & Source \\
\hline EHR System & $\begin{array}{l}\text { Whether or not hospital reports, at minimum, full } \\
\text { implementation of the following ten computerized } \\
\text { functions in at least one clinical unit of the hospital: } \\
\text { patient demographics, physician notes, nursing } \\
\text { assessments, patient problem lists, patient medication } \\
\text { lists, discharge summaries, laboratory reports, radiologic } \\
\text { reports, diagnostic test results, and order entry for } \\
\text { medications }\end{array}$ & Binary variable equal to 1 for "yes" and o for "no." & $\begin{array}{l}\text { Constructed by the author from raw survey data from } \\
\text { American Hospital Association (AHA) Annual Survey } \\
\text { Information Technology Supplement. Definition now } \\
\text { commonly accepted as that for a "basic" electronic health } \\
\text { record (EHR) system and used by Adler-Milstein, et al. } \\
\text { (2015) and Jha, et al. (2009), among many others. }\end{array}$ \\
\hline RN Union & $\begin{array}{l}\text { Whether or not the hospital's registered nurses (RNs) } \\
\text { have organized for the purpose of collective bargaining. }\end{array}$ & Binary variable equal to 1 for "yes" and o for "no." & $\begin{array}{l}\text { Constructed by the author from raw data on National } \\
\text { Labour Relations Board (NLRB) elections, contract } \\
\text { listings, work stoppages, unfair labour practice charges } \\
\text { (ULPs), and contract settlement summaries collected by } \\
\text { the private analytics firm Bloomberg/BNA. }\end{array}$ \\
\hline Social Welfare Share of Payer Mix & $\begin{array}{l}\text { Share of hospital patient days covered by Medicare or } \\
\text { Medicaid. }\end{array}$ & $\begin{array}{l}\text { Continuous measure of the proportion from } 0 \text { to } 1 \text { of total } \\
\text { patient days billed to Medicare or Medicaid as opposed to } \\
\text { private insurance companies or directly to patients. }\end{array}$ & $\begin{array}{l}\text { Constructed by the author from raw survey data from } \\
\text { American Hospital Association (AHA) Annual Survey } \\
\text { Database. }\end{array}$ \\
\hline Total Beds & $\begin{array}{l}\text { Total number of beds set-up and staffed at the hospital as } \\
\text { of the end of the reporting period. }\end{array}$ & Continuous count of the number of beds. & $\begin{array}{l}\text { American Hospital Association (AHA) Annual Survey } \\
\text { Database. }\end{array}$ \\
\hline Urban & $\begin{array}{l}\text { Whether or not the hospital is located in and serves an } \\
\text { urban area. }\end{array}$ & $\begin{array}{l}\text { Binary variable in which } 1 \text { implies a Core-Based Statistical } \\
\text { Area (CBSA) of "metropolitan" or larger and o implies a } \\
\text { CBSA defined as "rural" or "micropolitan." }\end{array}$ & $\begin{array}{l}\text { American Hospital Association (AHA) Annual Survey } \\
\text { Database. }\end{array}$ \\
\hline Hospital System Member & $\begin{array}{l}\text { Whether or not the hospital is one unit within a larger } \\
\text { system of hospitals. }\end{array}$ & Binary variable equal to 1 for "yes" and o for "no." & $\begin{array}{l}\text { American Hospital Association (AHA) Annual Survey } \\
\text { Database. }\end{array}$ \\
\hline League Member & $\begin{array}{l}\text { Whether or not the hospital is a member of the League of } \\
\text { Voluntary Hospitals and Homes New York (LVHH), and } \\
\text { thus, engages in multi-employer collective bargaining. }\end{array}$ & Binary variable equal to 1 for "yes" and o for "no." & $\begin{array}{l}\text { Constructed by the author from raw data on National } \\
\text { Labour Relations Board (NLRB) elections, contract } \\
\text { listings, work stoppages, unfair labour practice charges } \\
\text { (ULPs), and contract settlement summaries collected by } \\
\text { the private analytics firm Bloomberg/BNA as well as from } \\
\text { information contained in collective bargaining } \\
\text { agreements (CBAs) entered into and memoranda-of } \\
\text { understanding (MOAs) issued by the LVHH between } \\
2001 \text { and } 2014 \text {. }\end{array}$ \\
\hline
\end{tabular}


TABLE 2

Means, Standard Deviations, and Correlations for Study Sample of New York State Hospital-Years

\begin{tabular}{|c|c|c|c|c|c|c|c|c|c|}
\hline \# & Variable & Mean & SD & 1 & 2 & 3 & 4 & $\mathbf{5}$ & 6 \\
\hline 1 & EHR System & .36 & .48 & 1.00 & & & & & \\
\hline 2 & RN Union & .50 & .50 & $.07^{*}$ & 1.00 & & & & \\
\hline 3 & Social Welfare Share of Payer Mix & .72 & .16 & $-.09^{*}$ & $.25^{* * * *}$ & 1.00 & & & \\
\hline 4 & Total Beds & 344.2 & 319.8 & $.21^{* * * *}$ & $.12^{* * * *}$ & -.04 & 1.00 & & \\
\hline 5 & Urban & .77 & .42 & $.15^{* * * *}$ & .05 & $-.09^{*}$ & $.35^{* * * * *}$ & 1.00 & \\
\hline 6 & Hospital System Member & .50 & .50 & $.14^{* * * *}$ & $.10^{*}$ & $-.09^{* * *}$ & $.14^{* * * *}$ & $.16^{* * * *}$ & 1.00 \\
\hline 7 & League Member & .18 & .39 & $.14^{* * * *}$ & $.31^{* * * *}$ & $-.16^{* * * *}$ & $.39^{* * * *}$ & $.22^{* * * *}$ & $.15^{* * * *}$ \\
\hline
\end{tabular}

Notes: Table shows pairwise correlations for the study sample consisting of 827 hospital-years representing 165 distinct hospitals. * $p<.05, * * * 0.01, * * * *<<.001$. 
TABLE 3

Impact of Registered Nurse Unionization on the Likelihood That a Hospital Uses at Least a Basic Electronic Health Record System: Multilevel Linear Probability Models

\begin{tabular}{|c|c|c|c|c|c|}
\hline Variable & Model 1 & Model 2 & Model 3 & Model 4 & Model 5 \\
\hline \multirow[t]{2}{*}{ RN Union } & & .04 & .02 & .03 & $-.59^{* *}$ \\
\hline & & $(0.81)$ & $(0.28)$ & $(0.62)$ & $(-3.24)$ \\
\hline \multirow[t]{2}{*}{ Social Welfare Share of Payer Mix } & & & & $-.32 *$ & $-.61^{* * *}$ \\
\hline & & & & $(-2.54)$ & $(-4.91)$ \\
\hline \multirow[t]{2}{*}{ RN Union $\times$ Social Welfare Share of Payer Mix } & & & & & $.85^{* * * *}$ \\
\hline & & & & & $(3.43)$ \\
\hline \multirow[t]{2}{*}{$\ln ($ Total Beds $)$} & & & & $.07 * *$ & $.06^{*}$ \\
\hline & & & & $(2.66)$ & $(2.44)$ \\
\hline \multirow[t]{2}{*}{ Urban } & & & & .06 & .05 \\
\hline & & & & $(1.07)$ & $(0.93)$ \\
\hline \multirow[t]{2}{*}{ Hospital System Member } & & & & .04 & .03 \\
\hline & & & & $(0.86)$ & $(0.57)$ \\
\hline \multirow[t]{2}{*}{ League Member } & & & & .07 & .08 \\
\hline & & & & $(1.04)$ & $(1.19)$ \\
\hline \multirow{2}{*}{2009} & .03 & .03 & .03 & .03 & .03 \\
\hline & $(1.39)$ & $(1.39)$ & $(0.87)$ & $(1.33)$ & $(1.64)$ \\
\hline \multirow[t]{2}{*}{2010} & $.08^{* *}$ & $.08^{* *}$ & .05 & $.09^{* *}$ & $.09^{* *}$ \\
\hline & $(2.97)$ & $(2.97)$ & $(1.42)$ & $(3.15)$ & $(3.18)$ \\
\hline \multirow[t]{2}{*}{2011} & $.16^{* * * *}$ & $.16^{* * *}$ & $.11^{*}$ & $.16^{* * * *}$ & $.16^{* * * *}$ \\
\hline & $(4.59)$ & $(4.59)$ & $(2.54)$ & $(4.69)$ & $(4.70)$ \\
\hline \multirow[t]{2}{*}{2012} & $.32^{* * * *}$ & $.32^{* * * *}$ & $.29^{* * *}$ & $.33^{* * * *}$ & $.33^{* * * *}$ \\
\hline & $(7.45)$ & $(7.45)$ & $(4.88)$ & $(7.61)$ & $(7.42)$ \\
\hline \multirow[t]{2}{*}{2013} & $.45 * * * *$ & $.45 * * *$ & $.46^{* * * *}$ & $.46^{* * * *}$ & $.46^{* * * *}$ \\
\hline & $(9.56)$ & $(9.56)$ & $(6.81)$ & $(9.66)$ & $(9.77)$ \\
\hline \multirow[t]{2}{*}{2014} & $.63^{* * * *}$ & $.63^{* * * *}$ & $.66^{* * * *}$ & $.64^{* * * *}$ & $.64^{* * * *}$ \\
\hline & $(13.59)$ & $(13.58)$ & $(9.83)$ & $(13.65)$ & $(13.31)$ \\
\hline includes vector of $\mathrm{RN}$ Union $\times$ Year terms & no & no & yes & no & no \\
\hline pseudo- $R^{2}$ & .38 & .39 & .38 & .46 & .50 \\
\hline$\chi^{2}$ & $188.9^{* * * *}$ & $189.5^{* * * *}$ & $190.1^{* * * *}$ & $314.8^{* * * *}$ & $402.7 * * *$ \\
\hline clusters & 165 & 165 & 165 & 165 & 165 \\
\hline$n$ & 827 & 827 & 827 & 827 & 827 \\
\hline
\end{tabular}

Notes: Models are multilevel random effects linear probability estimates in which the dependent variable is whether or not the hospital uses at least a basic electronic health record (EHR) system (with $z$-statistics in parentheses) in a given year. Standard errors are clustered at the hospital level. Goodness-of-fit is assessed using the $R^{2}$-between statistic. * $p<.05, * * p<.01, * * * *<<.001$. 
TABLE 4

Impact of Registered Nurse Unionization on Whether and When a Hospital Adopts at Least a Basic Electronic Health Record System: Exponential Discrete-Time Hazard Models

\begin{tabular}{|c|c|c|c|c|c|}
\hline Variable & Model 1 & Model 2 & Model 3 & Model 4 & Model 5 \\
\hline \multirow[t]{2}{*}{ RN Union } & & .13 & -.02 & .09 & $-3.64^{* *}$ \\
\hline & & $(0.65)$ & $(-0.03)$ & $(0.42)$ & $(-3.26)$ \\
\hline \multirow[t]{2}{*}{ Social Welfare Share of Payer Mix } & & & & $-1.71^{*}$ & $-2.71^{* * * * *}$ \\
\hline & & & & $(-1.99)$ & $(-5.38)$ \\
\hline \multirow[t]{2}{*}{ RN Union $\times$ Social Welfare Share of Payer Mix } & & & & & $5.01^{* * * * *}$ \\
\hline & & & & & $(3.42)$ \\
\hline \multirow[t]{2}{*}{$\ln ($ Total Beds) } & & & & .16 & .15 \\
\hline & & & & $(1.31)$ & $(1.18)$ \\
\hline \multirow[t]{2}{*}{ Urban } & & & & .21 & .23 \\
\hline & & & & $(1.23)$ & $(1.17)$ \\
\hline \multirow[t]{2}{*}{ Hospital System Member } & & & & .10 & .07 \\
\hline & & & & $(0.74)$ & $(0.77)$ \\
\hline \multirow[t]{2}{*}{ League Member } & & & & .35 & .32 \\
\hline & & & & $(0.51)$ & $(0.37)$ \\
\hline \multirow[t]{2}{*}{2009} & -.56 & -.56 & -.56 & -.52 & -.42 \\
\hline & $(-1.13)$ & $(-1.13)$ & $(-0.80)$ & $(-1.07)$ & $(-0.89)$ \\
\hline \multirow[t]{2}{*}{2010} & .09 & .09 & -.62 & .15 & .19 \\
\hline & $(0.22)$ & $(0.22)$ & $(-0.88)$ & $(0.40)$ & $(0.52)$ \\
\hline \multirow[t]{2}{*}{2011} & -.12 & -.11 & -.51 & .01 & .07 \\
\hline & $(-0.26)$ & $(-0.24)$ & $(-0.72)$ & $(0.02)$ & $(0.15)$ \\
\hline \multirow[t]{2}{*}{2012} & $.92^{*}$ & $.93^{* *}$ & .87 & $1.05^{* * *}$ & $1.03 * *$ \\
\hline & $(2.57)$ & $(2.59)$ & $(1.75)$ & $(3.07)$ & $(3.03)$ \\
\hline \multirow[t]{2}{*}{2013} & $1.12^{* *}$ & $1.13^{* * *}$ & $1.22^{*}$ & $1.27^{*} * * *$ & $1.25^{* * * * *}$ \\
\hline & $(3.07)$ & $(3.08)$ & $(2.45)$ & $(3.54)$ & $(3.63)$ \\
\hline \multirow[t]{2}{*}{2014} & $1.79^{* * * * *}$ & $1.80^{* * * *}$ & $1.84^{\text {***** }}$ & $1.93^{* * * *}$ & $1.99^{* * * *}$ \\
\hline & $(5.41)$ & $(5.42)$ & $(4.01)$ & $(5.99)$ & $(6.34)$ \\
\hline includes vector of $\mathrm{RN}$ Union $\times$ Year terms & no & no & yes & no & no \\
\hline$\chi^{2}$ & $78.9^{\text {**** }}$ & $80.0^{* * * *}$ & 80.6 $6^{\text {****** }}$ & $106.4^{* * * * *}$ & 155.1 米** $^{2}$ \\
\hline subjects & 162 & 162 & 162 & 162 & 162 \\
\hline failures & 95 & 95 & 95 & 95 & 95 \\
\hline time at risk & 628 & 628 & 628 & 628 & 628 \\
\hline \multicolumn{6}{|c|}{$\begin{array}{l}\text { Notes: Table displays coefficients (with } z \text {-statistics in parentheses) from event history models estimated using an exponential } \\
\text { hazard parameterization to predict whether and when a hospital adopts at least a basic electronic health record (EHR) system, } \\
\text { where adoption is treated as a terminal event. Standard errors are clustered at the hospital level. }\end{array}$} \\
\hline$* p<.05, * * p<.01, * * * p<.001$ & & & & & \\
\hline
\end{tabular}


TABLE 5

Impact of Registered Nurse Unionization on Whether and When a

Hospital Adopts at Least a Basic Electronic Health Record System: Multilevel Linear Probability and Exponential Discrete-Time Hazard Models

Variable

Model 1 Model 2 Model 3 Model 4 Model 5 Model 6

RNs in Mixed Bargaining Unit

RNs in Exclusive Bargaining Unit

\begin{tabular}{|c|c|r|r|r|r|}
\hline-.02 & -.03 & -.53 & .05 & .05 & -2.18 \\
\hline$(-0.35)$ & $(-0.43)$ & $(-1.43)$ & $(0.19)$ & $(0.16)$ & $(-1.56)$ \\
\hline
\end{tabular}

Social Welfare Share of Payer Mix

\begin{tabular}{|r|r|r|r|r|r|}
\hline .07 & .06 & $-.59 * *$ & .16 & .11 & $-5.18^{* *}$ \\
\hline$(1.14)$ & $(1.06)$ & $(-3.11)$ & $(0.71)$ & $(0.44)$ & $(-2.72)$ \\
\hline
\end{tabular}

Mixed Bargaining Unit $\times$ Social Welfare Share of Payer Mix

\begin{tabular}{|c|c|c|c|}
\hline$-.32 * *$ & -.61 * $* * *$ & $-1.71^{*}$ & $-2.68 * * * *$ \\
\hline$(-2.58)$ & $(-4.88)$ & $(-1.97)$ & $(-5.21)$ \\
\hline
\end{tabular}

RNs in Exclusive Bargaining Unit $\times$ Social Welfare Share of Payer Mix

\begin{tabular}{|c|c|c|c|c|c|c|}
\hline & & & $(3.48)$ & & & $(2.86)$ \\
\hline \multirow[t]{2}{*}{$\ln ($ Total Beds $)$} & & $.07 * *$ & $.06^{*}$ & & .16 & .17 \\
\hline & & $(2.70)$ & $(2.49)$ & & $(1.29)$ & $(1.29)$ \\
\hline \multirow[t]{2}{*}{ Urban } & & .06 & .05 & & .21 & .23 \\
\hline & & $(1.14)$ & $(0.97)$ & & $(0.73)$ & $(0.77)$ \\
\hline \multirow[t]{2}{*}{ Hospital System Member } & & .04 & .03 & & .11 & .08 \\
\hline & & $(0.87)$ & $(0.55)$ & & $(0.52)$ & $(0.37)$ \\
\hline \multirow[t]{2}{*}{ League Member } & & .05 & .06 & & .33 & .23 \\
\hline & & $(0.74)$ & $(0.92)$ & & $(1.09)$ & $(0.72)$ \\
\hline \multirow[t]{2}{*}{2009} & .03 & .03 & .03 & -.56 & -.52 & -.41 \\
\hline & $(1.39)$ & $(1.34)$ & $(1.65)$ & $(-1.13)$ & $(-1.07)$ & $(-0.88)$ \\
\hline \multirow[t]{2}{*}{2010} & $.08^{* *}$ & $.09^{* *}$ & $.09^{* * *}$ & .09 & .15 & .19 \\
\hline & $(2.97)$ & $(3.14)$ & $(3.17)$ & $(0.22)$ & $(0.41)$ & $(0.52)$ \\
\hline \multirow[t]{2}{*}{2011} & $.16^{* * * * *}$ & $.16^{* * * *}$ & $.16^{* * * *}$ & -.11 & .01 & .06 \\
\hline & $(4.59)$ & $(4.69)$ & $(4.68)$ & $(-0.24)$ & $(0.03)$ & $(0.15)$ \\
\hline \multirow[t]{2}{*}{2012} & $.32 * * *$ & $.33 * * *$ & $.33^{* * * *}$ & $.93^{* *}$ & $1.05^{* *}$ & $1.07 * *$ \\
\hline & $(7.43)$ & $(7.59)$ & $(7.44)$ & $(2.60)$ & $(3.09)$ & $(3.22)$ \\
\hline \multirow[t]{2}{*}{2013} & $.45^{* * * *}$ & $.46^{* * * *}$ & $.46^{* * *}$ & $1.13^{*} *$ & 1.27 *** & $1.25^{* * *}$ \\
\hline & $(9.54)$ & $(9.66)$ & $(9.78)$ & $(3.10)$ & $(3.56)$ & $(3.67)$ \\
\hline \multirow[t]{2}{*}{2014} & $.63^{* * * *}$ & $.64 * * * *$ & $.64 * * *$ & $1.80^{* * * *}$ & 1.93*** & $2.01 * * *$ \\
\hline & $(13.54)$ & $(13.69)$ & $(13.41)$ & $(5.45)$ & $(6.02)$ & $(6.52)$ \\
\hline pseudo- $R^{2}$ & .38 & .46 & .50 & na & na & na \\
\hline$\chi^{2}$ & $204.6 * * *$ & $321.7 * * *$ & 424.0**** & $81.6^{* * *}$ & $107.7 * * * *$ & $164.6^{* * * *}$ \\
\hline clusters or subjects & 165 & 165 & 165 & 162 & 162 & 162 \\
\hline failures & na & na & na & 95 & 95 & 95 \\
\hline$n$ or time at risk & 827 & 827 & 827 & 628 & 628 & 628 \\
\hline
\end{tabular}

Notes: Table displays coefficients (with $z$-statistics in parentheses) and standard errors clustered at the hospital level. Models 1-3 are multilevel random effects linear probability estimates in which the dependent variable is whether or not the hospital uses at least a basic electronic health record (EHR) system in a given year. Goodness-of-fit for these models is assessed using the $R^{2}$-between statistic. Models 4-6 are event history models estimated using an exponential discrete-time hazard parameterization to predict whether and when a hospital adopts at least a basic EHR system, where adoption is treated as a terminal event. $* p<.05, * * *<.01, * * * *<<.001$. 
FIGURE 1

\section{Observed U.S. Hospital Adoption of At Least a Basic Electronic Health Record System, by Year}

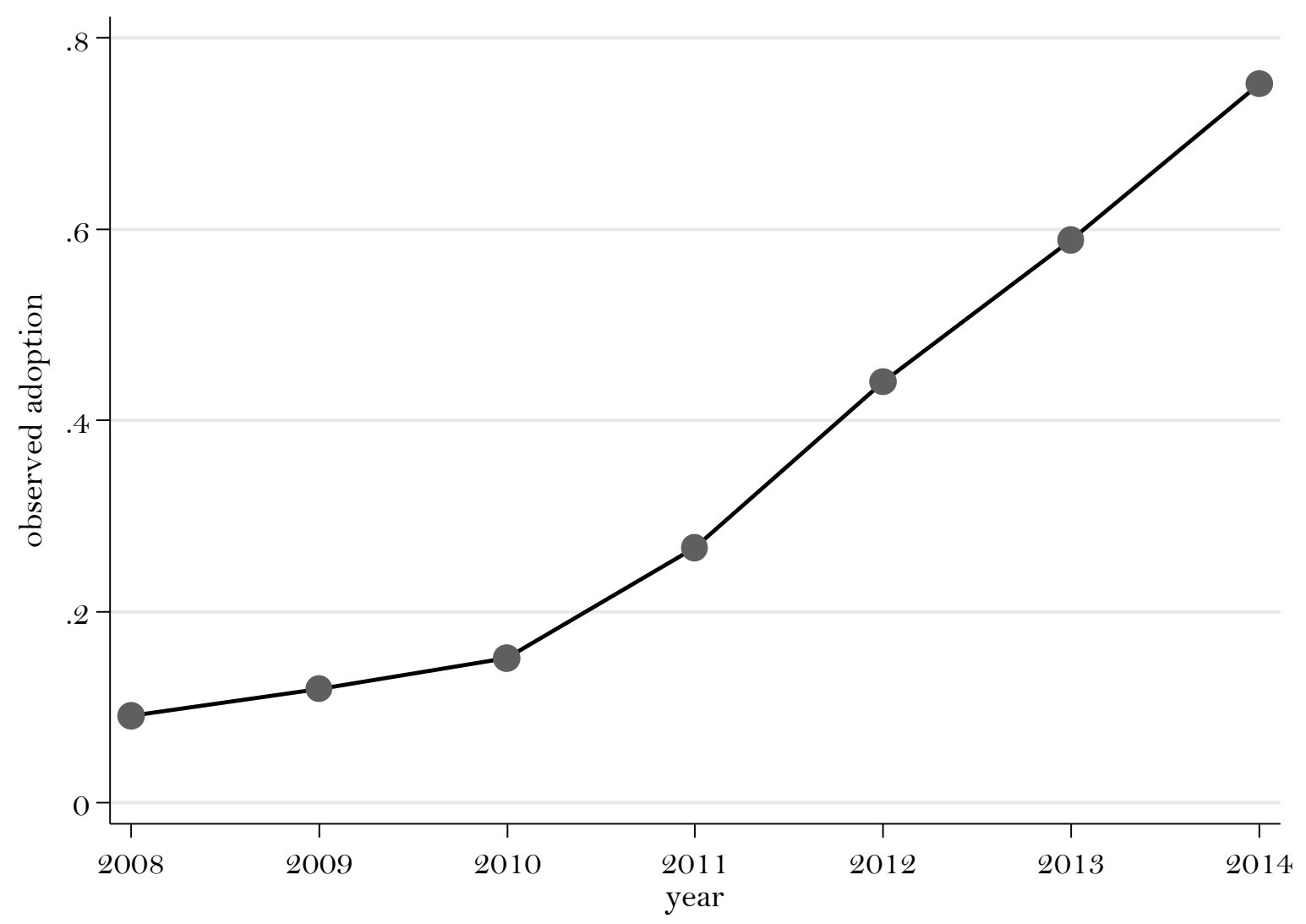

Notes: Chart measures U.S. national hospital adoption of at least a basic electronic health record (EHR) system, i.e., at minimum, full implementation of the following ten computerized functions in at least one clinical unit of the hospital: patient demographics, physician notes, nursing assessments, patient problem lists, patient medication lists, discharge summaries, laboratory reports, radiologic reports, diagnostic test results, and order entry for medications. Excludes federal hospitals, those located outside the fifty states or the District of Columbia, nonmedical institutions, and surgical institutions and centres.

Source: Author's analysis of raw data from the American Hospital Association (AHA) Annual Survey Information Technology Supplement as well as prior analyses undertaken using the same data (AdlerMilstein, et al. 2014, Adler-Milstein, et al. 2015, DesRoches, et al. 2013, DesRoches, et al. 2012, Jha, et al. 2011, Jha, et al. 2009, Jha, et al. 2010). 
FIGURE 2

\section{Characteristics of Nurses and Their Unions Relative to the U.S. Private Sector Overall}

(a.) Employment Growth

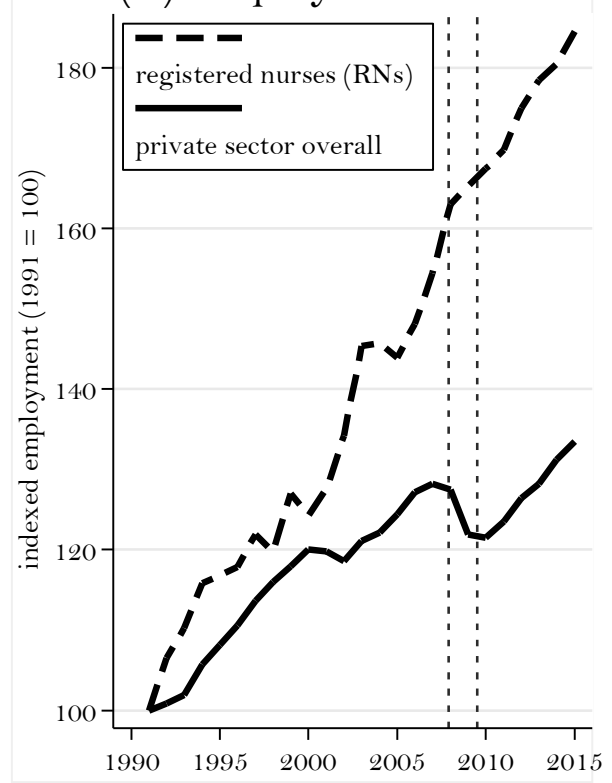

(c.) Union Density

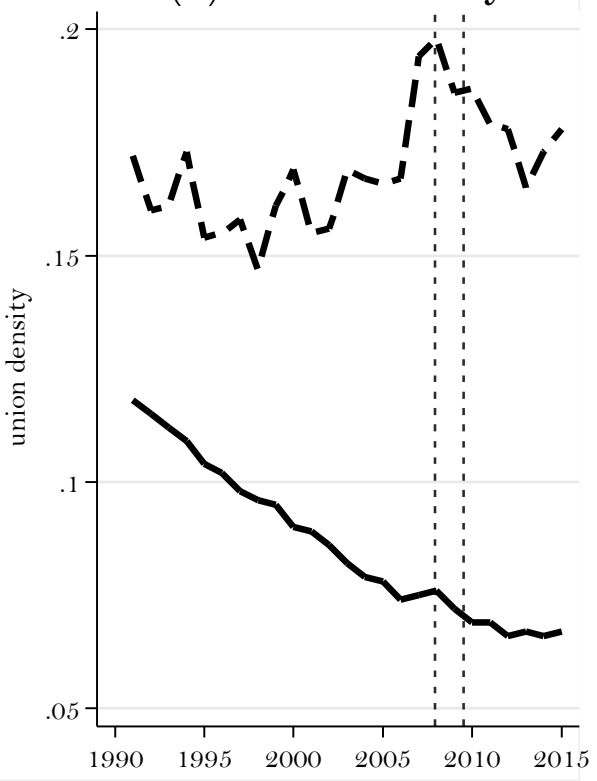

(b.) Wage Growth

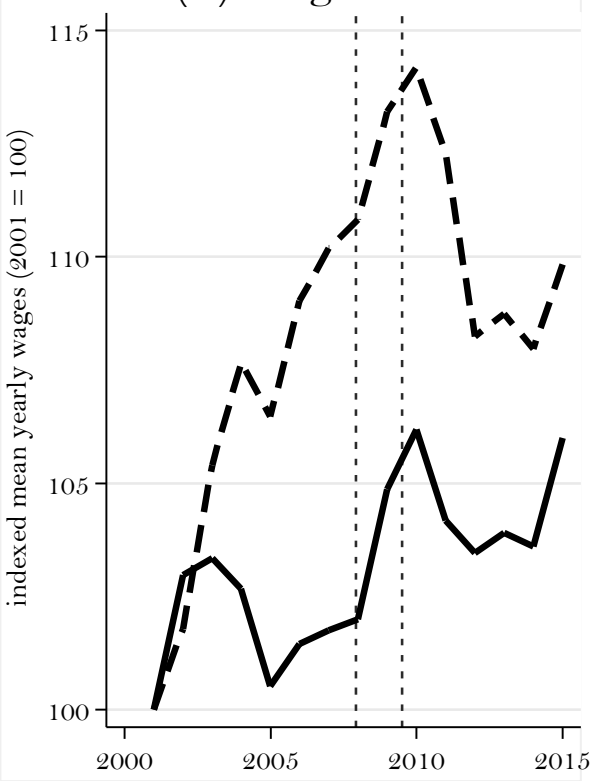

(d.) Change in Union Density

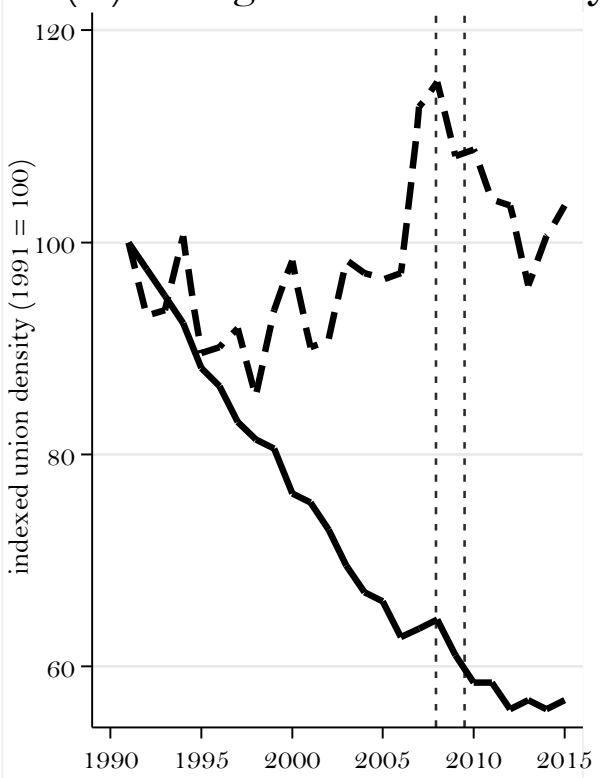

Notes: Homogenous wage data by occupation only reach back to 2001 . The large kink in the RN data series in panel (b.) results in part from a change in the construction of the series that took effect in 2012 and thus, can be disregarded. The dotted, vertical lines denote the beginning and end of the 2008 recession as defined by the National Bureau of Economic Research.

Source: The union data come from Hirsch and Macpherson (2016). The data on employment and wages come from the U.S. Bureau of Labour Statistics Occupational Employment Statistics. 
FIGURE 3

\section{Observed State-Level Hospital Adoption of At Least a Basic Electronic Health Record System, by Year}

(a.) Overall Adoption

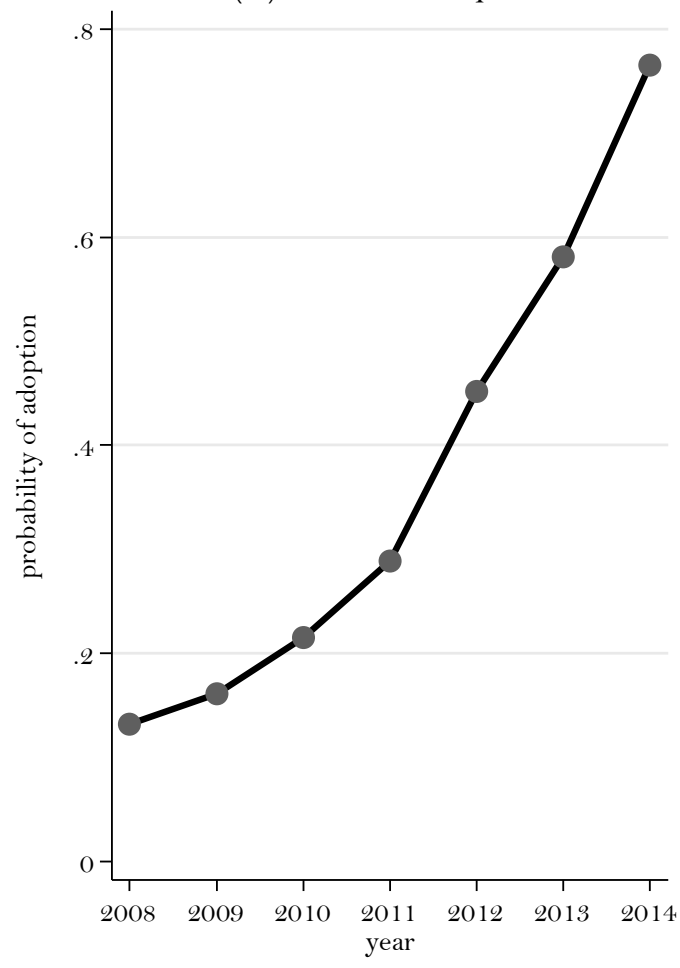

(b.) Adoption by RN Union Status

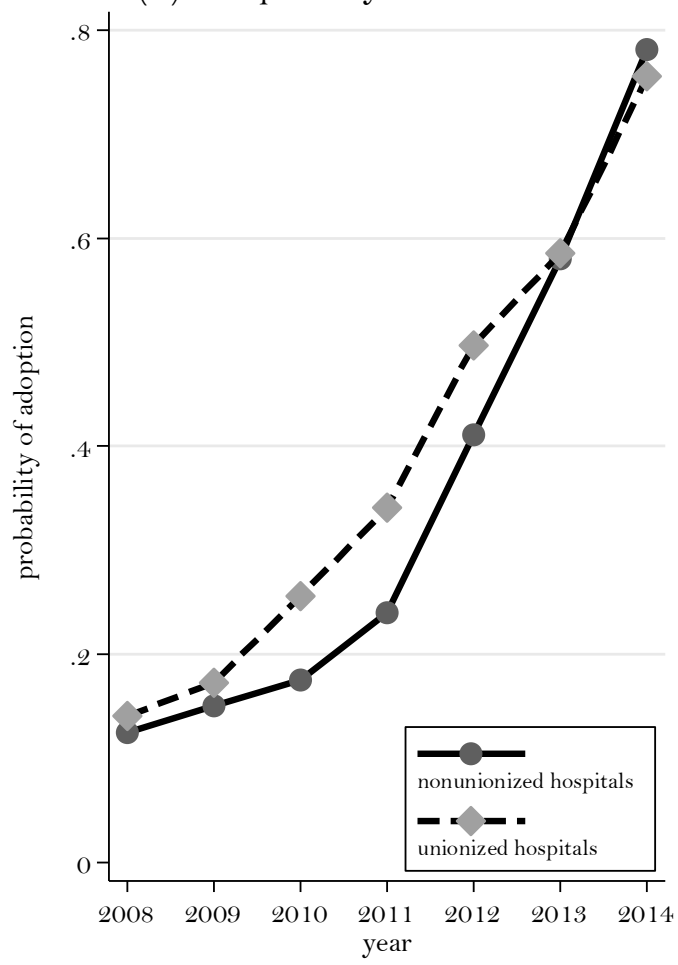

Notes: Charts measure New York State hospital adoption of at least a basic electronic health record (EHR) system, i.e., at minimum, full implementation of the following ten computerized functions in at least one clinical unit of the hospital: patient demographics, physician notes, nursing assessments, patient problem lists, patient medication lists, discharge summaries, laboratory reports, radiologic reports, diagnostic test results, and order entry for medications. Excludes federal hospitals, nonmedical institutions, and surgical institutions and centres. 
FIGURE 4

Fitted Probabilities and Median Log Survival Times of Hospital Adoption of At Least a Basic Electronic Health Record System over Time, by Government Share of Payer Mix and Registered Nurse Union Status
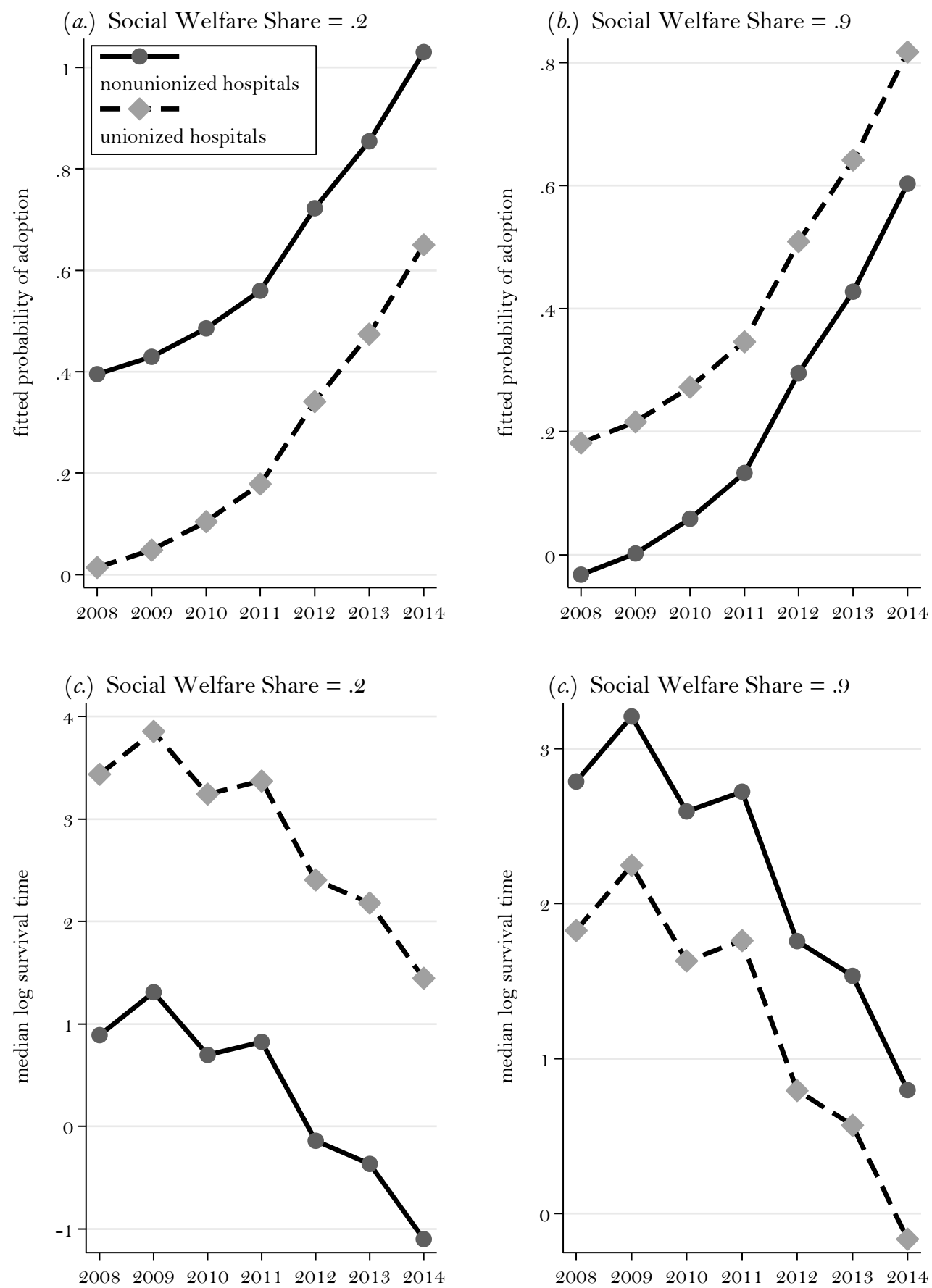

Notes: Panels $(a$.$) and (b$.) were fitted from Model 5 in Table 3 with all non-focal independent variables held at their sample means. They show the fitted probability that a hospital reports having at least a basic electronic health record (EHR) system in place in the survey year. Panels $(c$.) and $(d$.) were fitted from Model 5 in Table 4 with all non-focal independent variables held at their sample means. They show the median log time to EHR adoption. 